\title{
Gastric lipoma presenting with haematemesis
}

\author{
Madina Almohsin, Abdul-Wahed Nasir Meshikhes
}

Department of Surgery, King Fahad Specialist Hospital, Dammam, Eastern Province, Saudi Arabia

\section{Correspondence to} Dr Abdul-Wahed Nasir Meshikhes,

meshikhes@gmail.com

Accepted 14 January 2015

\section{DESCRIPTION}

A 61-year-old man presented to the local hospital with a 7-day history of epigastric pain, haematemesis, melaena and fatigability. Gastroscopy showed a gastric antral mass with an ulcer (figure 1A, B) and biopsies were negative for malignancy. The patient was transfused 2 units of blood and referred for further management. He was well with stable vital signs and an unremarkable abdominal examination. Repeat gastroscopy (figure 1C, D) and endoscopic ultrasound (EUS) showed a large hyperechoic lesion arising from the antral wall submucosa. Endoscopic biopsy revealed chronic non-specific gastritis and submucosal adipose fragments suggestive of lipoma. CT scan showed a large $(8.5 \times 5 \mathrm{~cm})$ submucosal well-encapsulated fat-containing antral lesion with thickened and ulcerated overlying tissue. The antrum was narrowed by the lesion, but there was no proximal gastric dilation (figure 2). The patient underwent laparotomy and enucleation of the lesion with some overlying gastric mucosa (figure 3 ). The histology confirmed lipoma with areas of focal necrosis. The patient remained well at 9-month follow-up.

Gastric lipomas are rare and account for 5\% of all gastrointestinal (GI) lipomas. ${ }^{1}$ They are most commonly located in the submucosal layer of the antrum and are often asymptomatic, and may be discovered incidentally. ${ }^{1}$ However, they may present with gastric outlet obstruction, intussusception, massive GI bleeding and, rarely, malignant transformation into liposarcoma. ${ }^{1-3}$ CT scan is often diagnostic showing well-circumscribed submucosal mass lesion with attenuated fat density ${ }^{2}$ (figure 2). EUS and endoscopic biopsy are also helpful in establishing a preoperative diagnosis. The treatment is surgical excision either by partial gastrectomy or enucleation. ${ }^{1}$ Endoscopic resection has been described. ${ }^{3}$
To cite: Almohsin $M$, Meshikhes A-WN. BMJ Case Rep Published online: [please include Day Month Year] doi:10.1136/bcr-2014206884
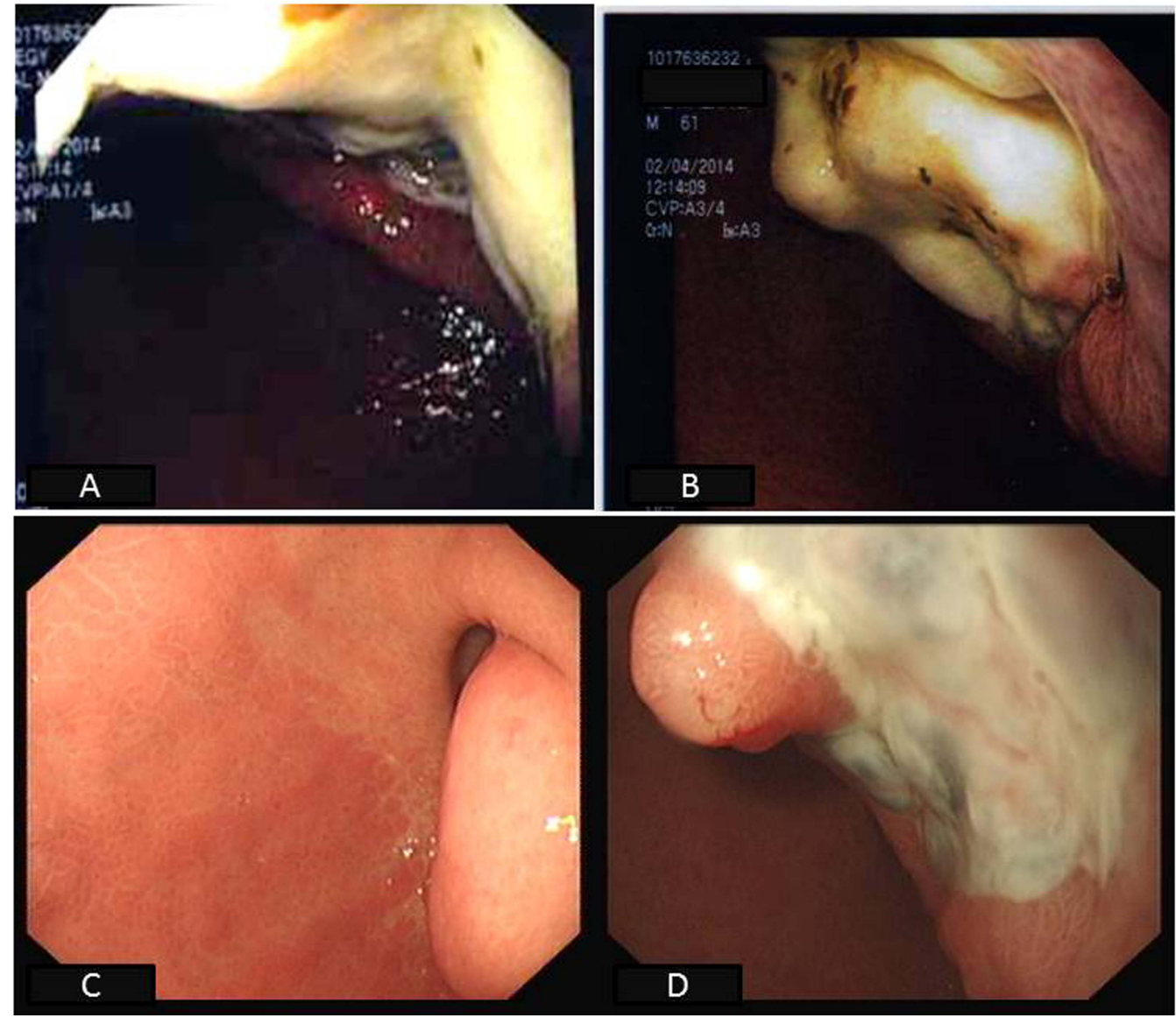

Figure 1 Endoscopic views of the antral lipoma during first presentation at the referring hospital. The ulcerated part that led to bleeding is clearly seen (A and $B)$. The repeat endoscopic views 1 week prior to surgery (C and $D)$. 
Figure 2 CT scan ((A) axial; (B) coronal view) of the abdomen showing the large well-encapsulated and fat-attenuated submucosal lesion $(8.5 \times 5 \mathrm{~cm})$ in the gastric antrum (yellow arrow), which was partially occluding the lumen without obstruction.
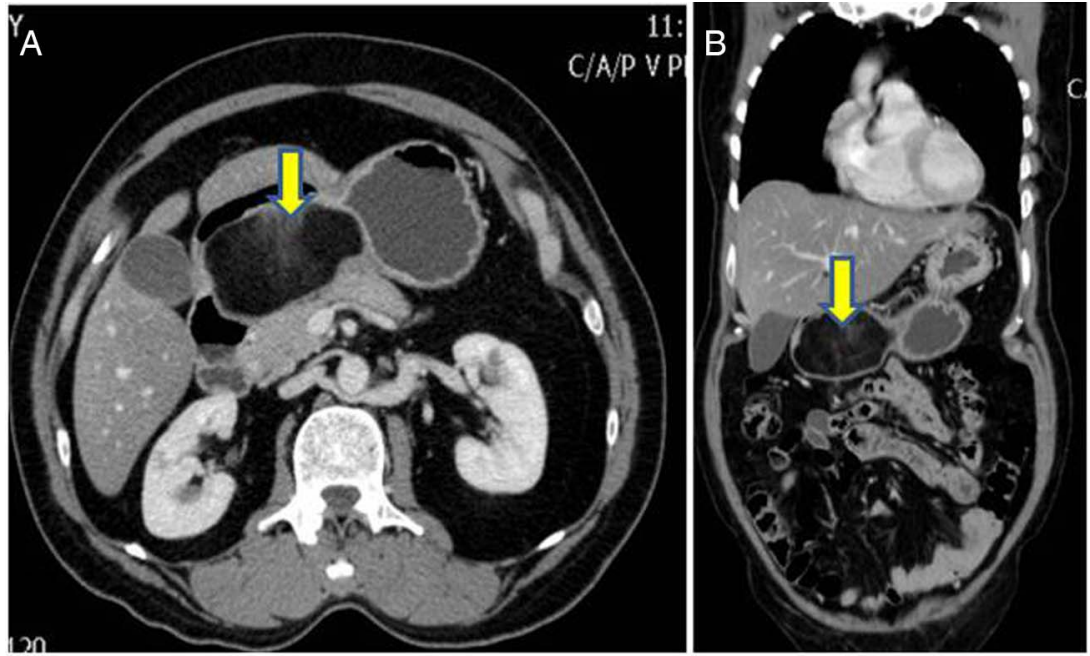

Learning points

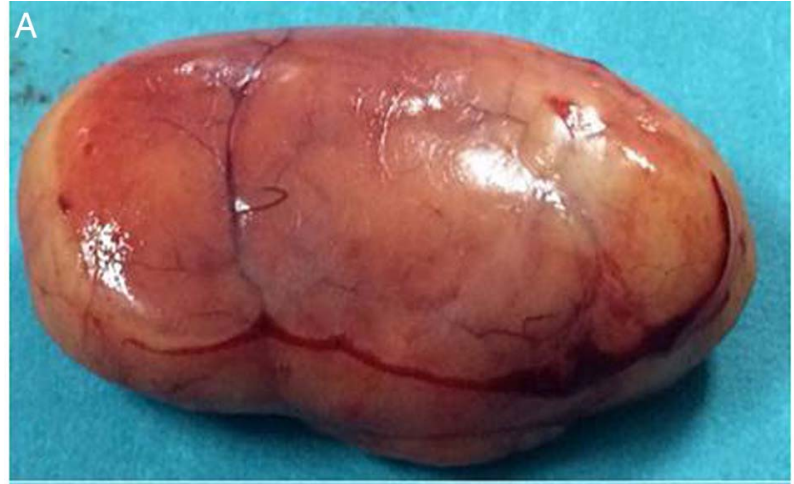

- Gastric lipomas may present with gastric outlet obstruction, massive gastrointestinal bleeding or intussusception.

- CT scan, endoscopic ultrasound and endoscopic biopsy help to establish the diagnosis preoperatively.

- Surgical enucleation is sufficient and can be conducted either laparoscopically or endoscopically.

Twitter Follow Abdul-Wahed Meshikhes at @meshikhes

Acknowledgements The authors would like to thank Dr Jawad BuSubaih consultant gastroenterologist of King Fahad Hospital, Hofouf, Saudi Arabia for providing figure $1 \mathrm{~A}, \mathrm{~B}$.

Contributors MA wrote the initial draft and searched the literature. A-WNM managed the case and wrote the final draft.

Competing interests None.

Patient consent Obtained.

Provenance and peer review Not commissioned; externally peer reviewed.

\section{REFERENCES}

1 Rao C, Rana SS, Lal A, et al. Large gastric lipoma presenting with GI bleeding. Gastrointest Endosc 2013;77:512-13.

2 Thompson WM, Kende Al, Levy AD. Imaging characteristics of gastric lipomas in 16 adult and pediatric patients. Am J Roentgenol 2003;181:981-5.

3 Matsushita M, Fukata N, Okazaki K. Endoscopic removal of large gastric lipomas: en bloc resection with submucosal dissection or partial resection with unroofing technique. Dig Endosc 2013;25:211-12.
Figure 3 The enucleated gastric lipoma ((A) posterior surface; $(B)$ anterior surface). 
Copyright 2015 BMJ Publishing Group. All rights reserved. For permission to reuse any of this content visit http://group.bmj.com/group/rights-licensing/permissions.

BMJ Case Report Fellows may re-use this article for personal use and teaching without any further permission.

Become a Fellow of BMJ Case Reports today and you can:

- Submit as many cases as you like

- Enjoy fast sympathetic peer review and rapid publication of accepted articles

- Access all the published articles

- Re-use any of the published material for personal use and teaching without further permission

For information on Institutional Fellowships contact consortiasales@bmjgroup.com

Visit casereports.bmj.com for more articles like this and to become a Fellow 